\title{
Gerald E. McClearn: Complexity in Behavior Genetics
}

\author{
George P. Vogler
}

Received: 11 October 2010/ Accepted: 15 October 2010/Published online: 3 November 2010

(C) Springer Science+Business Media, LLC 2010

\begin{abstract}
A festskrift in honor of the career contributions of Gerald E. McClearn was held in State College, Pennsylvania in May 2009. A selection of papers presented at that celebration is included in this issue of Behavior Genetics. These papers illustrate contemporary progress in research areas that have been chosen to reflect key aspects of Jerry's career accomplishments.
\end{abstract}

Keywords Behavior genetics · Alcohol use - Cognition · Aging · Mouse models · Twin research · Complex systems

Whether the issue at hand is current genetics of complex phenotypes in gerontology, historical perspective on most any topic in behavior genetics, human or animal research, novel ideas to integrate the features of complex systems analysis with genetics of complex traits, world events, or the latest historical mystery novel, a conversation with Jerry McClearn is sure to be informative, enlightening, and entertaining. With audiences as diverse as psychologists or geneticists, scientists with no behavioral or genetic background, seminar participants, students, or community members, Jerry has a remarkable ability to communicate the most advanced ideas about the complexity of genetic and environmental factors and their interplay in complex phenotypes with ease and clarity.

This ability to communicate new ideas effectively to diverse audiences was a key factor in Jerry's critical role in the development of behavior genetics as a field at a time

\section{G. P. Vogler $(\bowtie)$}

Department of Biobehavioral Health, The Pennsylvania State University, 315 East Health and Human Development Building, University Park, PA 16802, USA

e-mail: gpv1@psu.edu when there was substantial resistance to the perspective that genes could influence behavior. Along with others having similar vision, he fostered a bridge between psychologists (McClearn and Meredith 1966) and geneticists (McClearn 1970) and others as opportunities arose. His organizational skills were applied in the founding of the Institute for Behavioral Genetics at the University of Colorado, Boulder, in 1966. Of course, these contributions to the development of the field could be made only in the context of scientific contributions that served to define and advance the field over a period of more than half a century.

In recognition of his scientific contributions to behavioral genetics, psychology, alcohol use and abuse, aging, and complex systems, a festskrift entitled "Behavior, Genetics and Aging: A Lifetime Perspective" was held in his honor on May 8 and 9, 2009, at Penn State University in State College, Pennsylvania. This special issue of Behavior Genetics, a journal to which Jerry's contributions and efforts have contributed to its success, consists of five papers based on talks presented at that celebration.

Jerry has a broad perspective on species that can be used to understand differences in behavior. His early work included investigation of learning in rhesus monkeys (e.g., McClearn and Harlow 1954), but he was drawn to the advantages of using a mouse model to investigate genetics of behavior (McClearn 1959) and ultimately to the study of ethanol consumption behavior (McClearn et al. 1964). This interest led to the development of a multivariate process of selective breeding beginning with a genetically heterogeneous founding population of mice to provide an animal model for studying mechanisms potentially involved in ethanol withdrawal (McClearn et al. 1982). Ultimately, this line of research led to identification of interacting quantitative trait loci for alcohol-related traits (Fernández et al. 2000) and recognition of the need to apply the principles of 
complex systems to alcohol pharmacogenetics (McClearn 1993). The paper in this issue by Crabbe, Phillips, and Belknap address some of the complex issues involved in continuing efforts to identify genes for alcohol-related phenotypes.

Human cognition has been central to Jerry's work throughout his career. He has been involved in a number of influential studies that characterized the influence of genetic factors on cognition, including the Hawaii Family Study of Cognition (DeFries et al. 1976).

Several papers in this issue reflect the ongoing complexity of the nature of genetic influences on cognition. Wadsworth and colleagues demonstrate, using a twin design, that genetic influences on reading difficulties differ as a function of IQ. Davis and colleagues take a different approach, using a three-stage genome-wide association study to identify genes for general cognitive ability in children in the UK Twins Early Development Study. Their results confirm the likely complexity of genetic effects on general cognitive ability and identify challenges to identifying specific loci with small effect sizes.

In more recent work, Jerry has focused his research on the intriguingly challenging area of genetics of behavioral aging (McClearn 1991). This work integrates both animal studies (McClearn and Hofer 1999) and human work, including studies in collaboration with colleagues in Sweden on cognitive abilities in aging (McClearn et al. 1997). This Swedish collaboration has resulted in substantial contributions to the literature on genetics of $\operatorname{cog}$ nitive aging. The contribution to this issue by Gatz and colleagues illustrates a fascinating use of discordant samesex Swedish twins for identifying factors that predict the development of dementia (or reflect discordant changes related to preclinical disease).

As his career progresses, Jerry increasingly advocates research that recognizes the inherent complexity in the action and interaction of multiple genetic and environmental factors on complex behavioral outcomes (McClearn 2004, 2006). A theme throughout the festskrift was recognition of the complexity of genetic and environmental influences on complex behavioral traits. A novel methodological approach to the analysis of intra-person variation is presented by Nesselroade and Molenaar that uses the idiographic filter approach integrated with the ACE behavior genetics model using a P-technique factor analysis with dynamic factors extensions to model intra-person variation and change.

The talks presented at the festskrift presented a forwardlooking view of genetic and environmental influences on complex phenotypes through the lens of the interests and contributions of Jerry McClearn over a period of more than 50 years. While the speakers and audience expressed appreciation for the contributions he has made to the development of the field and to the science he has conducted and positions he has advocated, we look forward to continued progress in understanding genetics of complex behaviors in substance use, cognition, aging, and other areas from Jerry and from the many people-scientists and nonscientists-whose work has been influenced by his generosity of ideas.

\section{References}

DeFries JC, Ashton GC, Johnson RC, Kuse AR, McClearn GE, Mi MP, Rashad MN, Vandenberg SC, Wilson JR (1976) Parentoffspring resemblance for specific cognitive abilities in two ethnic groups. Nature 261(5556):131-133

Fernández JR, Tarantino LM, Hofer SM, Vogler GP, McClearn GE (2000) Epistatic quantitative trait loci for alcohol preference in mice. Behav Genet 30(6):431-437

McClearn GE (1959) The genetics of mouse behavior in novel situations. J Comp Physiol Psychol 52(1):62-67

McClearn GE (1970) Behavioral genetics. Annu Rev Genet 4:437-468

McClearn GE (1991) Genetic and environmental influences in behavioral aging. Exp Aging Res 17(2):84-85

McClearn GE (1993) Genetics, systems, and alcohol. Behav Genet 23(2):223-230

McClearn GE (2004) Nature and nurture: interaction and coactions. Am J Med Genet B Neuropsychiatr Genet 124B(1):124-130

McClearn GE (2006) Contextual genetics. Trends Genet 22(6): 314-319

McClearn GE, Harlow HF (1954) The effect of spatial contiguity on discrimination learning by rhesus monkeys. J Comp Physiol Psychol 47(5):391-394

McClearn GE, Hofer SM (1999) Genes as gerontological variables: genetically heterogeneous stocks and complex systems. Neurobiol Aging 20(2):147-156

McClearn GE, Meredith W (1966) Behavioral genetics. Annu Rev Psychol 17:515-550

McClearn GE, Bennett EL, Hebert M, Kakihana R, Schlesinger K (1964) Alcohol dehydrogenase activity and previous ethanol consumption in mice. Nature 203:793-794

McClearn GE, Wilson JR, Petersen DR, Allen DL (1982) Selective breeding in mice for severity of the ethanol withdrawal syndrome. Subst Alcohol Actions Misuse 3(3):135-143

McClearn GE, Johansson B, Berg S, Pedersen NL, Ahern F, Petrill SA, Plomin R (1997) Substantial genetic influence on cognitive abilities in twins 80 or more years old. Science 276(5318): $1560-1563$ 